\title{
THE MUSLIM BROTHERHOOD IN SYRIA AND ITS ROLE IN SYRIA'S CURRENT SITUATION
}

\author{
Małgorzata Samojedny \\ Department of Political and Legal Doctrines \\ Faculty of Law, Administration and Economics \\ University of Wroclaw
}

\begin{abstract}
The Muslim Brotherhood is a global organization with representatives in each Muslim or Muslim's minority country. According to its doctrine, the movement main goal is establishment of the Caliphate based on principles of Islam. This global organization is recognized in many countries as a terrorist organization and banned. But still, it is the most underestimated movement in the whole Islamic world. Its role in current situation in Syria is not widely known but relevant. Though, it is the main creator and the eminence grise of the Syrian conflict, nobody recognizes this movement as a threat. The Syrian Branch of Muslim Brotherhood, as longtime Assad's enemy, peruses to movement main goal, by stages: regime overthrow and authority takeover in Syria. The Author presents the role of the Muslim Brotherhood in Syrian conflict with historical background and the movement current multidimensional influences and goals.
\end{abstract}

Key words: Muslim Brotherhood, Syria, Assad, Arab Spring, Political Islam, Islamism

Establishing a new movement based on the Islamic concepts of state, society and law developed in response to French and British colonial policy at the cusp of the nineteenth and twentieth centuries. The first attempts to constitute real ideological opposition to European influences appeared in Egypt. The Western enlightenment had a huge impact on Egyptian society. During that time the first newspapers were published and many medical, technical, science books were translated to into Arabic. The process of westernization in Egypt has begun. ${ }^{1}$ At the same time, a rival model based on Islam, called the Islamic Revival, was also developing. The Western movement was secular and based on the principles of science, mind and humanism. The Islamic one was strongly referenced to the

1 J. Zdanowski, Bracia Muzułmanie i inni, Szczecin 1986, p. 30. 
guidelines of Islam. The main movement of the doctrine of the Islamic Revival was the Muslim Brotherhood (Ikhwan, MB). ${ }^{2}$

The movement was established in Egypt in 1928 by Hassan al-Banna. He received a religious education based on Hanbali's school of Islamic jurisprudence. ${ }^{3}$ This radical model of Islamic interpretation was, and remains, totally opposite to the modern model of enlightened Islam and democratic values. Hanbali's model refers to the first two generations of Muslims (sixth century CE), and their model of life, law, state and social order. ${ }^{4}$

The main ideological goal of the Muslim Brotherhood, was educating youth and encouraging adults to self-improvement, of course in the conservative and traditional spirit of Islam. The Muslim Brotherhood was established as a global organization with agencies in every country where Muslims or Muslim minorities live. The movement's mission was a concept of global Muslim unity and an Islamic model of development based on the principle that Islam is not only a religion, but also a legal order, social order, way of life, and solution to every problem that may occur even in the secular sphere of life. ${ }^{5}$ The motto of the movement said a lot: "Allah our objective. The prophet is our exemplar. The Quran is our law. Jihad ${ }^{6}$ is our way. Dying in the way of Allah is our highest hope." What wonders more, the motto in no longer present on the Brotherhood official publications. ${ }^{7}$

When we examine the history of the movement we can see its astonishing capability to accommodate its rhetoric and actions to current political, social or economic situation and gains for the Ikhwan. All moves of the Muslim Brotherhood are analyzed and are a part of the greater idea. Therefore, during almost a century of movement activity, we can notice that the strategy but not the principles have changed. Flexibility and fitting skills allowed the Brotherhood to extend a global web of influences, without questions or obstacles. ${ }^{8}$

The Muslim Brotherhood had numerous representatives in Syria. After Egypt, it was the second country under such strong influence of the movement. The first information about the Muslim Brotherhood in Syria appeared in 1937. In Damascus the Ikhwan branch office was established before World War II. The greatest impact of the new ideology was on students and youth, called Shabab Muham-

2 J. Zdanowski, Bracia ..., p. 32.

3 M. Samojedny, Sunnickie Szkoty Prawa Muzulmańskiego, Acta Erasmiana t. V Varia, Wydawnictwo: Wydział Prawa, Administracji i Ekonomii Uniwersytetu Wrocławskiego, Wrocław 2013, p. 198.

4 M. Samojedny, Wyktadnia Prawa Islamu wedtug Hanbalickiej Szkoły Prawa, Wrocławskie Studia Erazmiańskie t. VIII Rozprawa o metodzie prawa i polityki, Wydawnictwo: Wydział Prawa, Administracji i Ekonomii Uniwersytetu Wrocławskiego, Wrocław 2014. p. 227.

5 J. Zdanowski, Bracia..., p. 32.

6 M. Sadowski, Dżihad - święta wojna w islamie, Przegląd Bezpieczeństwa Wewnętrznego VIII, Warszawa 2013, p. 29.

7 http://www.clarionproject.org/sites/default/files/Muslim-Brotherhood-Special-Report.pdf p. 4, access: 27.07.2016

8 J. Zdanowski, Bracia ..., p. 140. 
mad. ${ }^{9}$ Strong French influences contributed to the movement's popularity in Syria. The French attempted to make Syria a colony. Their impact on religion was to promote of Christianity, on language to promote French in administration and books, and their impact on Islamic tradition was to promote the western model of equality, liberty and ethics. These caused an ideological rebellion. These oppressive efforts were a fertile background for the re-Islamisation of Syrian society. ${ }^{10}$

Initially, the movement's activities were concentrated in big cities - Aleppo and Hama. These two areas were the movement's main centers until the Muslim Brotherhood was outlawed in 1982. ${ }^{11}$

From the time the French left Syria until the Baath Party coup, the Muslim Brotherhood was growing in strength. During twelve years of Brotherhood activity in Syrian politics, its popularity was shown by an increase in holding seats in Parliament, which increased from three to ten. ${ }^{12}$ The Baath Party coup and the change in Syria's political situation caused infighting in the movement concerning its strategy toward the new Syrian political leader - Baath Party. Older leaders opted for peaceful talks. The second wing, dominated by younger members, was against any negotiations and called for militant resistance to the Baath Party regime. ${ }^{13}$ The more radical faction overthrew the old leaders and the character of the Muslim Brotherhood in Syria became violent and rebellious. An analogous situation took place in Egypt, where Sayyid Qutb became the movement's ideological leader and the Secret Apparatus ${ }^{14}$ masterminded its activity. In both countries, the movement's new path was manifested in recognizing secular and liberal governments as un-Islamic and, therefore, unauthorized to govern. Both branches, under new leadership, were calling for the regimes' overthrow. ${ }^{15}$

\section{THE MUSLIM BROTHERHOOD AND AL-ASSAD'S REGIME}

In the beginning, Hafiz Al-Assad's takeover in 1970s was supposed to give a new opportunity for the resumption of negotiations. But in fact it was the beginning of the end for the Muslim Brotherhood in Syria. Tensions between the regime and the rebels were closing in. The apple of discord was Assad's constitutional

9 J. Zdanowski, Bracia ..., p. 148.

10 W. R. Polk, Understanding Syria: from Pre-Civil War to Post-Assad, http://www.theatlantic.com/international/archive/2013/12/understanding-syria-from-pre-civil-war-to-post-as$\operatorname{sad} / 281989 /$, access: 03.08.2016.

${ }^{11}$ J. Zdanowski, Bracia ..., p. 148.

${ }^{12}$ L. Porad, The Syrian Muslim Brotherhood and the Asad Regime, Middle East Brief 47, Weltham 2010, p. 1.

${ }^{13}$ L. Porad, The Syrian..., p. 2.

${ }^{14}$ Secret Apparatus - the Muslim Brotherhood military forces, formed in 1940s, ardent supporters of the Ikhwan's doctrine implementation by force.

${ }^{15}$ L. Porad, The Syrian ..., p. 2. 
amendment. The Syrian constitution stated that Islam is the president's religion, and Islamic jurisprudence is the source of all legislation. Assad, as a representative of the Alawi ${ }^{16}$ community, was not meeting the rules for keeping power or governing. This change wasn't approved by the Ikhwan. But this matter was not the only conflict between these two power claimants. In time, the main political goal for the Syrian Muslim Brotherhood was the overthrow of Hafiz al-Assad's regime. ${ }^{17}$

In second half of the 1970s the struggle became violent. In June 1979, the Ikhwan's military troops attacked Alawi's Military Academy and killed thirty-two cadets. The group stated that it was a response to the Assad regime's repression of the Muslim Brotherhood. The extensive repression against members of the movement started after the failure of an assassination attempt against Assad on $26^{\text {th }}$ of June 1980. The regime's terror machine was put into motion. Arrests, seizures, tortures, executions were common in those days. In Palmyra prison over one thousand Ikhwan members or supporters were executed. The regime decided to wipe out the Muslim Brotherhood in Syria. To achieve this goal, a new law went into effect in July 1980--Decree 49 was passed by the Syrian People's Council and in first article has stated: “(...) each and every one belonging to the Muslim Brotherhood organization is considered a criminal who will receive a death punishment (...)"'18. With this law, the Ikhwan was declared illegal and characterized as a criminal and terrorist organization. Consequent$l y$, the movement's members and supporters were declared to be enemies of the state. However, there was a possibility to spare life: “(...) if a member declared withdrawal from the Muslim Brotherhood in one month from the date this law goes into effect (...)." This regulation didn't apply to those in detention or under trial. ${ }^{19}$ Under the second article of Decree 49, 1052 Ikhwan members turned themselves in, according to government reports. ${ }^{20}$

The Muslim Brotherhood was still active despite the extremely dangerous repression. In Aleppo and Hama, where the movement's influence was widespread, the violent struggles were an everyday fact of life for a few months. The final clash of regime forces and rebel troops took place on February 1982 in the city of Hama. Suppression ended with thousands of casualties, the crushing of the Brotherhood and its leader's exile. Some fled to Arab countries, mostly Saudi Arabia, others settled in Europe. In 1990s the Syrian Muslim Brotherhood office was established in London. ${ }^{21}$

Though the Syrian Ikhwan lost its official representatives, the movement's idea was still alive among Syrians, because its network was not completely

${ }^{16}$ Alawis - Shia Muslims, who believe in reincarnation, drink during services. Ethnic and religious minority group along Syria's west coast.

${ }^{17}$ L. Porad, The Syrian..., p. 3.

${ }^{18} \mathrm{http}: / /$ www.shrc.org/en/?p=19753, access: 03.08.2016.

$19 \mathrm{http}: / /$ www.shrc.org/en/?p=19753, access: 03.08.2016.

${ }^{20}$ L. Porad, The Syrian..., p. 3.

${ }^{21}$ Ibidem. 
demolished. Because of Assad's Decree 49, the movement's strategy had to be changed. During that tough time, the main goal was to keep movement's clutches in Syrian society. The lost struggle with the regime forced the Ikhwan to look for a new way to overthrow the Assad regime. The Brotherhood's new strategy was based on propaganda against Assad and a battle for young Syrians' souls. The new path sought to promote the movement's ideology and a concept of state based on principles of Islam. It was a quite simple task in a society where the Sunni Muslims were a majority but repressed and marginalized by the regime. ${ }^{22}$ For all these years Ikhwan activists had been cooperating with numerous organizations. If the regime noticed any connections with the Muslim Brotherhood, each organization was declared illegal and members were repressed. ${ }^{23}$ That Brotherhood's stealthy demeanor can be perceived as intentional. Certainly it was an elimination of a competitor in building an image as Assad's main opposition in Syria.

During all these years of extending conflict, we can notice short moments of ceasefire. In 1990s we can see a softening of regime policy towards the Brotherhood. From the other side, the movement's rhetoric towards Assad was less aggressive. However, this thaw in relations was short-term. The Brotherhood was counting on policy changes when Bashar al-Assad took power in 2000 after his father's death. Initially, it seemed that reaching an agreement might be possible. ${ }^{24}$

In 2005 representatives of many Syrian opposition movements signed the Damascus Declaration. Unified Sunni opposition demanded peaceful reforms of the political system, equality of all citizens, a secular and sovereign Syria, and above all multiparty democracy. ${ }^{25}$ However the ideas of the Declaration were impossible to implement. The Damascus Declaration was not approved by the Al-Assad regime and led to further arrests. Twelve opposition parties' signatories were imprisoned. The ways of the Assad regime did not change. This failed attempt to start any negotiations confirmed the validity of the Muslim Brotherhood's call for Assad's overthrow and establishing the new model of the Syrian state, based on principles of Islam and Sharia Law. In 2010, in one of the Ikhwan's statements, these demands remained unchanged. ${ }^{26}$

An interesting thread of Assad-Ikhwan relations was the case of Hamas. The Muslim Brotherhood linkage with Hamas is official. It is confirmed by Article 2 of the Charter of Hamas, which reads: "The Islamic Resistance movement is one of the wings of the Muslim Brothers in Palestine". ${ }^{27}$ So it is quite surprising that Hamas opened a political office in Damascus, under Khaled Mashal's man-

${ }^{22}$ L. Porad, The Syrian ..., p. 4.

${ }^{23}$ Ibidem.

${ }^{24}$ L. Porad, The Syrian..., p. 5.

${ }^{25} \mathrm{http} / / /$ carnegieendowment.org/syriaincrisis/48514, access 03.08.2016

${ }^{26}$ L. Porad, The Syrian ..., p. 5.

${ }^{27} \mathrm{http} / / /$ www.gatestoneinstitute.org/4297/muslim-brotherhood-ansar-bayt-al-maqdis, access: 23.07.2016. 
agement, in 2001. Mashal lived in Syria for eleven years, from 2001 until the civil war started in 2011, but then he left the country. ${ }^{28}$ It is worth mentioning that the Decree 49 remained.

\section{THE IKHWANI, ARAB SPRING AND CIVIL WAR IN SYRIA}

In 2011 Arabic society loudly demanded removal of governing authority and the implementation of a democratic multiparty system based on liberal values. This new wave of protest also reached Syria. However, it has to be noticed that politics was not initially the spark that fired up Syria. Political and religious aspects came later and in fact took advantage of people's simple frustration. For the few previous years Syria was plagued with terrible drought. Income per capita dropped from $\$ 5000$ to $\$ 2900$. Agriculture became insufficient, so people left villages and moved to towns, in search of bread. But there was nothing waiting for them. All those frustrations - the state that was not able to provide citizen's basic needs, injustice, corruption and ethnic conflicts--effected the revolution, which ended with political and religious civil war. ${ }^{29}$

The Muslim Brotherhood saw an opportunity in the chaos to officially come back to Syria as the rightful opposition to the Assad's regime. On $23^{\text {rd }}$ of September 2011 a statement was posted on the official website of the Brotherhood's Syrian branch calling for continuing the revolution until the Assad's regime was overthrown and a free Syria arises. ${ }^{30}$ Additionally, in a statement posted two weeks later, Muhammad Reiad Al-Shaqfa stated that there is no need for foreign military intervention in Syria. ${ }^{31}$ This statement is worth remembering, because it shows that the Brotherhood intended to manage the situation using its own potential. Since the Damascus Declaration was signed, the rhetoric of the movement has changed. The statements and demands were focused on equality, humanism, liberty and democratic values, which are not exactly coherent with the Ikhwan's doctrine. So it is quite possible that this kind of demeanour is again just to improve the movement's public image, especially in international public opinion. ${ }^{32}$ We can assume that the takeover in 2012 by Egypt's Ikhwan is a confirmation of this strategy. The Muslim Brotherhood's new Egyptian constitution was based on movement's doctrine, not its declarations. So the statement posted on the movement's website on $7^{\text {th }}$ of April 2012: "The Syrian Muslim Brotherhood declares new Covenant that

${ }^{28}$ P. Seale, The Syrian Timebomb, http://foreignpolicy.com/2011/03/29/the-syrian-timebomb-2/, access: 25.07.2016.

${ }^{29}$ W. R. Polk, Understanding...

${ }^{30} \mathrm{http} / / / \mathrm{www} . i k h w a n w e b . c o m /$ article.php?id=29060\&ref=search.php, access: 22.07 .2016 .

${ }^{31} \mathrm{http} / /$ www.ikhwanweb.com/article.php?id=29376\&ref=search.php, access: 27.07 .2016$.

32 A. Dzisiów-Szuszczykiewicz, Arabska Wiosna - przyczyny, przebieg i prognozy, Bezpieczeństwo Narodowe XVIII, Warszawa 2011, p. 53. 
reassures world community that new post-Bashar Syria will be a State of justice and rule of law, equality, stability and peace" ${ }^{33}$ is quite amusing.

Initially in 2011, the Ikhwan was undoubtedly the strongest anti-Assad opposition fraction, though its leaders were in exile. At that time, it was the only organized political force able to take over after Assad's overthrow. ${ }^{34}$ If that had happened quickly this scenario was possible. But the regime was standing still. Also, there were several opposition factions and the influence of the Brotherhood on Syrian youth was not that powerful. Currently, Salafism is gaining on popularity among young Syrians. ${ }^{35}$ It became the Ikhwan's main competitor to seize Syria. So again, the movement has to change its strategy. Therefore, the Brotherhood supported the rebel side along with numerous Salafi troops. ${ }^{36}$ As mentioned before, Ikhwan political leaders were in exile, but they marked their presence in Syria through Syrian National Council, a Syrian opposition coalition established in Istanbul on August 2011. More secular opposition actions argued that the Ikhwan dominated the organization. In response to this accusation, a broader organization - National Coalition for Syrian Revolutionary and Opposition Forces--was established in 2012, but that did not stop the infighting. The secular wing was outraged by the Muslim Brotherhood's disdainful and stealthy demeanour. The potential of the Muslim Brotherhood was still growing. In April 2013, for the first time since Decree 49 proclamation, an official Ikhwan office was established in Syria. It was opened as an answer to the demands of the people. Again, the Brotherhood's decision was accurate for movement gains. Organizing a party in rebel-held land under the Brotherhood brand capitalized on the increasingly Islamized Syrian society. It was the right time to reorganize and unleash the Ikhwan's ideology. In areas under the rebel's authority, the movement even runs a newspaper. According to declarations it is published in 10.000 copies. $^{37}$

Why does the Muslim Brotherhood feel so secure in Syria that it even loudly declares its pivot to pure doctrine? The rise of Islamic State of Iraq and Syria allowed the movement to slyly distance itself from extremism. The Ikhwan's Islamism, compared to radical Jihadi-Salafism with its barbaric violence and ruthless sharia law, appears quite rational and modern. Paradoxically, the establishment of the Islamic State was a benefit for the movement, because if the regime collapses only they will be the real victors. With their political background, prepared administrative apparatus, and organized structure, they will be able to efficiently govern.

${ }^{33} \mathrm{http} / / /$ www.ikhwanweb.com/article.php?id=29851\&ref=search.php, access: 27.07 .2016 .

${ }^{34} \mathrm{http}$ ://carnegieendowment.org/2013/05/07/struggling-to-adapt-muslim-brotherhood-innew-syria/g2qm, access: 26.07.2016.

${ }^{35}$ Ibidem.

${ }^{36} \mathrm{http} / /$ www.clarionproject.org/sites/default/files/Muslim-Brotherhood-Special-Report.pdf, access: 24.07.2016.

${ }^{37} \mathrm{https}$ ://www.washingtonpost.com/world/middle_east/exiled-muslim-brotherhoodplans-return-to-syria/2013/04/25/1160739a-adc6-11e2-98ef-d1072ed3cc27_story.html, access: 24.07.2016. 
ISIS will never be accepted by international public opinion. It is quite possible that the Syrian branch of the movement learned its lesson from the Brotherhood rule in Egypt and Morsi's overthrow. If the situation does not evolve, the Ikhwan could be a party in final negotiations on Syria's future.

On $4^{\text {th }}$ of September 2014 the former leader of the Muslim Brotherhood in Syria stated that ISIS is a great threat to the Syrian Revolution. ${ }^{38}$ Though ISIS was condemned by the movement, it does not mean that it does not cooperate with groups or organizations recognized as terrorist. Particularly during the war, when the possibility of establishing a state based on the Ikhwan's doctrine was at stake. We have to remember that for decades the Ikhwan's motto was calling for Jihad, and it was recognized as terrorist organization by many countries. Jihad has a special place in Muslim Brotherhood history. Currently a major Islamic theologian Yosuf al-Qaradawi, in an essay published in 2001, states that the Muslim Brotherhood has "engaged in real jihad battles, (...), sent the best of its sons to sacrifice" ${ }^{39}$ So though the leadership does not admit to any connection with armed troops now in Syria, it is widely known, that the members in exile found small paramilitary troops on the rebel side. ${ }^{40}$ In May 2012 the Commission of the Revolution's Shields (CSR) was established. It is a pro-Ikhwan coalition, but officially it was a moderate Islamist alliance that fights for human rights. Now it has been revealed as the movement's semiofficial armed wing. ${ }^{41}$ The CSR is not the only armed organization connected with the Ikhwan. The movement has its clutches in Sham Legion ${ }^{42}$, the Commission for the Protection of Civilians, which funds armed anti-Assad troops ${ }^{43}$ and the Free Syrian Army. But most interesting is the Brotherhood - Al-Qaeda linkage. A former president of Egypt, Muhammad Morsi, one of the leaders of the Egyptian branch of the Muslim Brotherhood, was charged with treason. He and the Ikhwan's government cooperated with the foreign terrorist organization Al-Qaeda against the national security of Egypt. ${ }^{44}$ It is documented that Morsi subsidized Al-Qaeda with \$25 million to organize, found and assemble the armed jihadi troops to support the Muslim Brotherhood. But what is really interesting in the Syrian civil war context is that the Al-Qaeda leadership also declared cooperation of its branches outside Egypt. ${ }^{45}$ Therefore we can assume that Al-Nusra, the Syrian branch of Al-Qaeda, cooperates with the

\footnotetext{
${ }^{38} \mathrm{http} / /$ www.ikhwanweb.com/article.php?id=31782\&ref=search.php, access: 22.07 .2016 .

${ }^{39} \mathrm{http}: / /$ www.gatestoneinstitute.org/4297/muslim-brotherhood-ansar-bayt-al-maqdis, access: 23.07.2016.

${ }^{40} \mathrm{http}: / /$ carnegieendowment.org/2013/05/07/struggling-to-adapt-muslim-brotherhood-innew-syria/g2qm, access: 26.07.2016.

${ }^{41}$ Ibidem.

${ }^{42} \mathrm{http} / / /$ carnegieendowment.org/syriaincrisis/?fa=62239, access: 28.07 .2016 .

${ }^{43} \mathrm{http} / / /$ carnegieendowment.org/syriaincrisis/?fa=53518, access: 27.07 .2016 .

${ }^{44} \mathrm{http}: / /$ www.raymondibrahim.com/2014/02/04/exposed-the-muslim-brotherhoodal-qaeda-connection/, access: 23.07.2016.

${ }^{45} \mathrm{http}$ //www.clarionproject.org/news/former-egyptian-jihad-leader-morsi-offered-25-milal-qaeda\#, access: 24.07.2016.
} 
Ikhwan as an armed wing of the movement. During last days, Al-Qaeda dismissed Al-Nusra from its pledge.

In my opinion Al-Qaeda, and its widespread branches is the Secret Apparatus of the Muslim Brotherhood, an armed, violent fraction of the superficial modern Islamist organization. The current leader of Al-Qaeda - Ajman Az-Zawahiri-joined the Muslim Brotherhood at age fourteen. The connections of former leaders of this terrorist organization with Ikhwan are even clearer. What's more wondering, in one of his interviews Yusuf al-Qaradawi states that Islamic State leader Abu Bakr Al-Baghdadi - was originally a member of the Muslim Brotherhood. ${ }^{46}$

According to these circumstances, let me hypothesize that the Arabic Spring chaos was caused and is utilized by the Ikhwan. It may not have caused it directly, but the widespread connections, years of propaganda currently gain for the movement. What is worth mentioning is that in 2011 was created a Facebook page "Syrian Revolution 2011", currently with over one and a half million likes. ${ }^{47}$ This page helped to set the character of the Syrian Revolution in its early days. During that time, it was the most widely read website. It created the most popular slogans that crowds were shouting during demonstrations. Though the page is officially independent, the network running it has direct connections with the Syrian Muslim Brotherhood. ${ }^{48}$

\section{CONCLUSIONS}

The Muslim Brotherhood is the largest Islamic organization, with worldwide connections, political strategy, a well-organized administration and a great number of representatives. This movement has been active for almost a century and keeps spreading its influence in political, cultural and social spheres of any country where Muslims or Muslim minorities live. ${ }^{49}$ Its goal is to impact every aspect of daily life in order to establish a truly Islamic world order. As a global network with an unhurried strategy, it can prepare a background of future actions. During recent years, the first takeover attempt took place in Egypt. Though it initially succeeded, this first Muslim Brotherhood government was overthrown by the army with public consent. But the Muslim Brotherhood took it as lesson learned. Therefore, in Syria the strategy will be different, but the gain is still the same - building the Caliphate.

\footnotetext{
${ }^{46} \mathrm{https}: / /$ www.youtube.com/watch? $\mathrm{v}=$ isVqB05a3o, access: 23.07.2016.

${ }^{47} \mathrm{https} / / / w w w . f a c e b o o k . c o m / S y r i a n . R e v o l u t i o n$, access: 23.07.2016.

${ }^{48} \mathrm{http}: / /$ carnegieendowment.org/2013/05/07/struggling-to-adapt-muslim-brotherhood-innew-syria/g2qm, access: 27.07.2016.

${ }^{49} \mathrm{http} / / / \mathrm{www}$.gatestoneinstitute.org/4297/muslim-brotherhood-ansar-bayt-al-maqdis, http:// www.gatestoneinstitute.org/4297/muslim-brotherhood-ansar-bayt-al-maqdisaccess: 23.07.2016.
} 


\section{BIBLIOGRAPHY}

1. Zdanowski J., Bracia Muzutmanie i inni, Szczecin 1986.

2. Samojedny M., Sunnickie Szkoły Prawa Muzułmańskiego, Acta Erasmiana t. V Varia, Wydawnictwo: Wydział Prawa, Administracji i Ekonomii Uniwersytetu Wrocławskiego, Wrocław 2013.

3. Samojedny M., Wykładnia Prawa Islamu wedtug Hanbalickiej Szkoły Prawa, Wrocławskie Studia Erazmiańskie t. VIII Rozprawa o metodzie prawa i polityki, Wydawnictwo: Wydział Prawa, Administracji i Ekonomii Uniwersytetu Wrocławskiego, Wrocław 2014.

4. Sadowski M., Dżihad - święta wojna w islamie, Przegląd Bezpieczeństwa Wewnętrznego VIII, Warszawa 2013.

5. Polk W. R., Understanding Syria: from Pre-Civil War to Post-Assad, http://www.theatlantic.com/ international/archive/2013/12/understanding-syria-from-pre-civil-war-to-post-assad/281989/.

6. Porad L., The Syrian Muslim Brotherhood and the Asad Regime, Middle East Brief 47, Weltham 2010.

7. Seale P., The Syrian Timebomb, http://foreignpolicy.com/2011/03/29/the-syrian-time-bomb-2/.

8. Dzisiów - Szuszczykiewicz A., Arabska Wiosna - przyczyny, przebieg i prognozy, Bezpieczeństwo Narodowe XVIII, Warszawa 2011.

9. http://carnegieendowment.org/syriaincrisis/?fa $=62239$.

10. http://carnegieendowment.org/syriaincrisis/?fa $=53518$.

11. http://www.raymondibrahim.com/2014/02/04/exposed-the-muslim-brotherhoodal-qaeda-connection/.

12. http://www.clarionproject.org/news/former-egyptian-jihad-leader-morsi-offered-25-mil-al-qaeda\#.

13. https://www.youtube.com/watch? $v=$ isVqB05a3o.

14. https://www.facebook.com/Syrian.Revolution.

15. http://carnegieendowment.org/2013/05/07/struggling-to-adapt-muslim-brotherhood-in-newsyria/g2qm.

16. http://www.gatestoneinstitute.org/4297/muslim-brotherhood-ansar-bayt-al-maqdis http://www. clarionproject.org/sites/default/files/Muslim-Brotherhood-Special-Report.pdf .

17. http://www.shrc.org/en/?p=19753.

18. http://carnegieendowment.org/syriaincrisis/48514.

19. http://www.ikhwanweb.com/article.php?id=29060\&ref=search.php.

20. http://www.ikhwanweb.com/article.php?id=29376\&ref=search.php.

21. http://www.ikhwanweb.com/article.php?id=29851\&ref=search.php.

22. http://carnegieendowment.org/2013/05/07/struggling-to-adapt-muslim-brotherhood-in-newsyria/g2qm.

23. https://www.washingtonpost.com/world/middle_east/exiled-muslim-brotherhood-plans-returnto-syria/2013/04/25/1160739a-adc6-11e2-98ef-d1072ed3cc27_story.html.

24. http://www.ikhwanweb.com/article.php?id=31782\&ref=search.php. 